\section{A twilight adventure}

\author{
John Launer
}

Many years ago, before the age of the internet, I picked up a collection of short stories called A Month of Mystery, edited by the film director Alfred Hitchcock. Most of the stories were humdrum, but one of them struck me as a masterpiece. It was by an American writer from the early 20th century named Melville Davisson Post. Although I never came across his writing again, his name stuck in my mind. Earlier this year, on a whim, I Googled him, and discovered that some of his works were still in print. I ordered a volume of his mystery stories, read them, and have been possessed by them ever since. More to the point, I have been thinking of how they could be used as a way of teaching doctors to examine own reasoning processes.

Davisson Post was a lawyer who gave up his career because of ill health before becoming a writer. By general agreement, his best writing appears in his so-called Uncle Abner stories. ${ }^{1}$ Each of these tales is written by a man named Martin, recalling events from his childhood, all of them centred on memories of a much loved uncle. Abner is a farmer, born not long after colonial times. A righteous, God-fearing man, he is endowed with wisdom and analytic judgement-a revered pillar of his community. Where there are crimes or mysteries to be solved, Abner is there, able to discern the truth among the lies and evasions of ordinary men's narratives.

Abner is often accompanied by a local magistrate, Squire Randolph. Unlike Abner, Randolph is learned in the law. A kind of Dr Watson figure to Abner's Sherlock Holmes, Randolph blunders into offering the obvious solution to every conundrum-and, inevitably, gets it wrong. Abner, by contrast, follows the subtle hints of suspects' language and the signs of nature to determine the correct, if entirely unexpected, answers.

\section{WRONG ANSWERS}

Once you have read a few of the stories, you learn to recognise the pattern and you try to guess in advance what conclusions

Correspondence to Dr John Launer, London Deanery, London Department of Postgraduate Medical Education, Stewart House, London WC1B 5DN, UK;

jlauner@londondeanery.ac.uk
Uncle Abner will reach. Davisson Post is far too masterly a writer to let you get away with it, and he lays false trails that will lead you into errors that-while not quite as egregious as Squire Randolph's-are still the wrong answers. Such a pattern of misdirection has of course become standard for the whole genre of mystery writing, most notably for authors like Conan Doyle or Agatha Christie, although historically Davisson Post may have invented the pattern.

However, the stories contain some elements that I believe mark Davisson Post out as a greater writer than any of his rivals. In many of these plots, for example, we discover that Abner was himself a participant in the events under examination. Sometimes he turns out to have been an unseen witness. At other times it becomes clear he had prior knowledge of the events. Once this is revealed, there is no sense of authorial trickery. Indeed, in retrospect, Abner's own hidden involvement in these events always seems both inevitable and obvious. Related to this, Davisson Post depicts Abner as a representative of moral justice. When justice and the law coincide, Abner makes sure both are observed. If the law-at least in Squire Randolph's pedantic version-is not the same as moral justice, Abner stays silent, and men who are technically guilty, but deserve compassion, retain their freedom and their lives. There is a sense in which Abner appears as the agent of God.

\section{MEDICAL REASONING}

When I first read Davisson Post I was not yet at medical school. Returning to his stories at the other end of a medical career, they make me think of the distinction between sound medical reasoning and its opposite: the impulse to leap to the wrong conclusion, on the basis of inadequate evidence and a lack of ethical commitment or self-awareness. The medical thinker he most reminds me of is another American, Jerome Groopman. In his classic book How Doctors Think, ${ }^{2}$ Groopman, a professor of medicine at Harvard Medical School, describes countless cases of how doctors make mistakes in diagnosis. With a cold eye, he analyses the reasons for these mistakes, including outcome bias, confirmation bias, diagnosis momentum, and in particular the 'availability heuristic'-the tendency we have to favour the diagnoses that come to mind most easily because they are familiar. Essentially, however, nearly all the mistakes that doctors make boil down to the same thing: a disregard for uncertainty, and its corollary, arrogance. I have a feeling that Uncle Abner and Jerome Groopman would have got on well.

Uncle Abner may have got on equally well with an Italian psychiatrist called Gianfranco Cecchin. Cecchin wrote eloquently on the subjects of neutrality and curiosity, and their application to clinical work. Like Groopman, he described the way we often go for the first explanation that comes to mind and thus restrict our capacity to think of more complex or more interesting descriptions of why things happen as they do. "When we assume that we have an explanation," he wrote "we often give up looking for other descriptions. Thus, we give up a stance of curiosity because we believe we have discovered a description that fits; description tends to help us avoid a neutral stance in that it does not enhance our curiosity". ${ }^{3}$ Cecchin was one of the first people to coin the phrase "being wedded to your hypothesis"; he proposed that we often fall in love with our own ideas so much that we are unable to separate from them even when they become unsustainable.

\section{LYNCHING PARTY}

The processes that Groopman and Cecchin describe are illustrated beautifully in the tale that enthralled me years ago, and appears in the volume I purchased recently. It is called $A$ Twilight Adventure. Abner and his young nephew are riding through the hills of Virginia when they come upon a lynching party, about to hang two cattle rustlers who they believe have murdered a local farmer the day before, to steal his herd. The men doing the lynching insist that there is no way Abner will stop them. Abner demands they should at least explain their reasons for assuming the victims' guilt. They give a detailed account of how one of their gang, a man named Bowers, came across the scene of the crime. The account is so persuasive that we cannot see how Abner can possibly challenge it.

Of course that is exactly what he does, starting first of all with an explanation of how people are drawn into false reasoning. "What circumstantial evidence proves," Abner explains to the men, "depends a good deal on how you get started. It is a somewhat dangerous road 
to the truth, because all the signboards have a curious trick of pointing in the direction you are going. Now, a man will never realise this unless he turns around and starts back. Then he will see, to his amazement, that the signboards have also turned. But as long as his face is set one certain way, it is of no use to talk to him, he won't listen to you; and if he sees you going the other way, he will call you a fool."

Having said this, Abner not only points out the flaws in their case but persuades them, dramatically, that the person who carried out the crime was really Bowers himself, who is at that moment knotting the noose.

\section{JUDICIAL PROCESS}

So far so good, but what happens next is even more instructive in helping us think about hypotheses and how we can become wedded to them. The lynch gang, convinced by Abner's argument, now turn on Bowers, determined to hang him in place of their previous victims. Bowers' only possible defence is that he claims he saw a man on horseback on a hill above the crime scene, who watched some of the events on the previous day, and could back up his story. His companions laugh at this feeble alibi and ask Uncle Abner if he really believes there was any such person. "My uncle seemed to increase in stature," the story goes on, "and his voice became big and dominant." "I do," he said, "because I am the man."

Bowers, it turns out, was telling the truth. The two cattle rustlers were guilty after all. We realise that Abner had known this all along. His only purpose had been to make sure there was a proper judicial process. Suitably chastened, the gang members abandon the lynching and lead the cattle rustlers off to a legal trial. As Abner tells the men, "I have shown merely whither circumstantial evidence leads when we go hotfoot after a theory."

Competing interests None.

Provenance and peer review Commissioned; internally peer reviewed.

Postgrad Med J 2011;87:653-654.

doi:10.1136/postgradmedj-2011-130351

\section{REFERENCES}

1. Davisson Post M. Uncle Abner: Master of Mysteries. Dodo Press, 2011.

2. Groopman J. How Doctors Think. Boston: Houghton Mifflin, 2007.

3. Cecchin G. Hypothesizing, circularity, and neutrality revisited: an invitation to curiosity. Fam Process 1987:26:405-13. 